\title{
Et blik ind i den \\ nye europæiske \\ sikkerhedsarkitektur
}

Af Ulrik Trolle Smed

Ved udgangen af sidste år drøftede EU's forsvarsministre EU's globale strategi for europæisk sikkerhedsog forsvarspolitik. De gennemgik implementeringen af det nye europæiske forsvarssamarbejde (PESCO) og den europæiske forsvarsfond, og ikke mindst spørgsmål om militær mobilitet, et nyt europæisk militært hovedkvarter og den civilmilitære forbindelse til en europæisk fredsfacilitet.

I løbet af de sidste to år har EU arbejdet med at styrke det europæiske forsvar i fuld respekt for de enkelte medlemsstaters forfatningsmæssige ansvar og nationale forsvarsforpligtelser. Nye samarbejdsplatforme inden for EU-rammen sigter mod at gøre Europa militært stærkere og operationelt

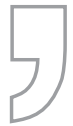

Som den nye Udenrigs- og Sikkerhedspolitiske Strategi for 2019-2020 skriver, så er verden et bedre sted end nogensinde før, men det internationale regelbaserede samarbejde er under massivt pres og verden er i hastig forandring.

mere effektivt. Alt sammen i dansk interesse, men meget af det uden dansk deltagelse.

Vi lever i en særlig geopolitisk tid, og det er værd at forstå konteksten for de forandringer som den nye forsvarsramme berører. Som den nye Udenrigs- og Sikkerhedspolitiske Strategi for 2019-2020 skriver, så er verden et bedre sted end nogensinde før, men det internationale regelbaserede samarbejde er under massivt pres og verden er i hastig forandring.

Ulrik Trolle Smed er politisk analytiker ved Det Europæiske Center for Politisk Strategi, Europa-Kommissionen. Synspunkterne i denne artikel er ikke nødvendigvis udtryk for EuropaKommissionens holdninger. Det Europæiske Center for Politisk Strategi er Europa-Kommissionens egen interne tænketank. Artiklen bygger desuden videre på en kronik bragt i mediet Altinget d. 22. november 2018 ['EU-tænketank: Dansk forsvar skal ikke parkeres på sidelinjen']. 


\section{I en verden, der bringer Europa under stigende pres, er} der behov for et Europa, der kan passe på sig selv og på andre, når der er behov for det.

Sådan ser verden også ud fra Bruxelles. På den økonomiske side har EU oplevet vækst i 21 kvartaler i træk, og skabt næsten 12 millioner nye job siden 2014. Investeringer for næsten 400 mia. euro er blevet hjulpet på vej med den Europæiske Fond for Strategiske Investeringer (EFSI). Og med nye fælles handelsaftaler i hus med Japan, Singapore, Mexico og mange flere har EU nu sikret sig et vækstgrundlag med 70 lande, der tilsammen udgør 40 pct. af det globale BNP.

Budskabet er klart: Sammen kan vi mere. Og det er vigtigt at holde sig in mente, fordi økonomisk succes og innovation er ikke længere forbeholdt Vesten. Det globale økonomiske tyngdepunkt er for længst begyndt rejsen mod Asien. Den asiatiske andel af det globale BNP er steget støt og er i dag næsten 'on-par' med OECD-landene i kølvandet på en enorm transformation de sidste to årtier.

Magtpolitik er ved at gøre 'comeback' med hårde militære kapabiliteter som styrkeindikatoren. Med Storbritanniens potentielle udtræden af EU ville den europæiske andel af globale forsvarsinvesteringer falde fra en anden- til en tredjeplads, nu overhalet af Kina. Samtidig er vi trådt ind i en ny tidsalder hvor skjulte online påvirkningskampagner, cyberangreb og indblanding i demokratiske valgprocesser er ved at danne ny normal - også i EU.

Demokratiet er også i bredere forstand under pres med 12 års på hinanden følgende fald i internationale indekser, herunder særligt pressefriheden - også i EU. Og med en stigning på næsten 50 pct. i antallet af handelsprotektionistiske tiltag globalt over det seneste årti er der sat alvorligt spørgsmål ved den liberale verdensorden.

Verden er ved at vokse sig større, og Europas plads i den skrumper sammen med robustheden af vores demokratiske værdier og samfund. Den barske sandhed er, at Brexit kun kommer til at øge udfordringen.

Det er baggrunden for en ny analyse i mange europæiske hovedstader, herunder Bruxelles. Og som svar på det skiftende geopolitiske billede har europæiske ledere besluttet at styrke den fælles europæiske sikkerheds- og forsvarspolitik med en forståelse af, at ingen medlemsstat kan håndtere det 21 . århundredes komplekse sikkerhedspolitiske udfordringer alene.

\section{Strategisk autonomi og friheden til at tage ansvar} I en verden, der bringer Europa under stigende pres, er der behov for et Europa, der kan passe på sig selv og på andre, når der er behov for det.

Det står efterhånden klart, at Europa ikke længere vil være tyngdepunktet i den amerikanske strategiske tænkning. Selvom den amerikanske administration har søgt at genetablere tilliden til amerikansk militær tilstedeværelse og sikkerhedsgaranti på det europæiske kontinent, så har tvivlen sat sig.

Samtidig har udviklingen vist de europæiske regeringer, at der skal en 
række byggesten til for at sikre en troværdig europæisk evne til at passe på sig selv og andre - med eller uden amerikanerne. Det inkluderer bl.a. fælles kapabilitetsudvikling, flere ressourcer til sikkerhed og forsvar, en styrkelse af den fælles sikkerheds- og forsvarspolitik, intensiveret samarbejde mellem medlemsstaternes væbnede styrker og fortsat udbygget samarbejde med partnere såsom NATO og institutionens medlemmer.

Det Europæiske Råd har tydeliggjort, at der er behov for et passende niveau af europæisk strategisk autonomi, når det kommer til udvikling, erstatning og drift af forsvarskapacitet samt centrale strategiske teknologiske områder for at kunne bevare teknologisk kompetence samt en folkelig forståelse af forsvarsudgifterne i Europa. Men også for rent faktisk at kunne påtage sig og udføre den regionale sikkerhedsopgave, eksempelvis i Nordafrika eller Mellemøsten.

Ligeledes har EU-institutionerne været helt klare omkring Unionens mål. Samarbejdet mellem EU og NATO er skredet støt frem, og EU har søgt at løse strategiske bekymringer af fælles interesse for $\mathrm{fx}$ både amerikanere og europæere med projekter som militær mobilitet. I forlængelse af EU's globale strategi har både Rådet og Euro-

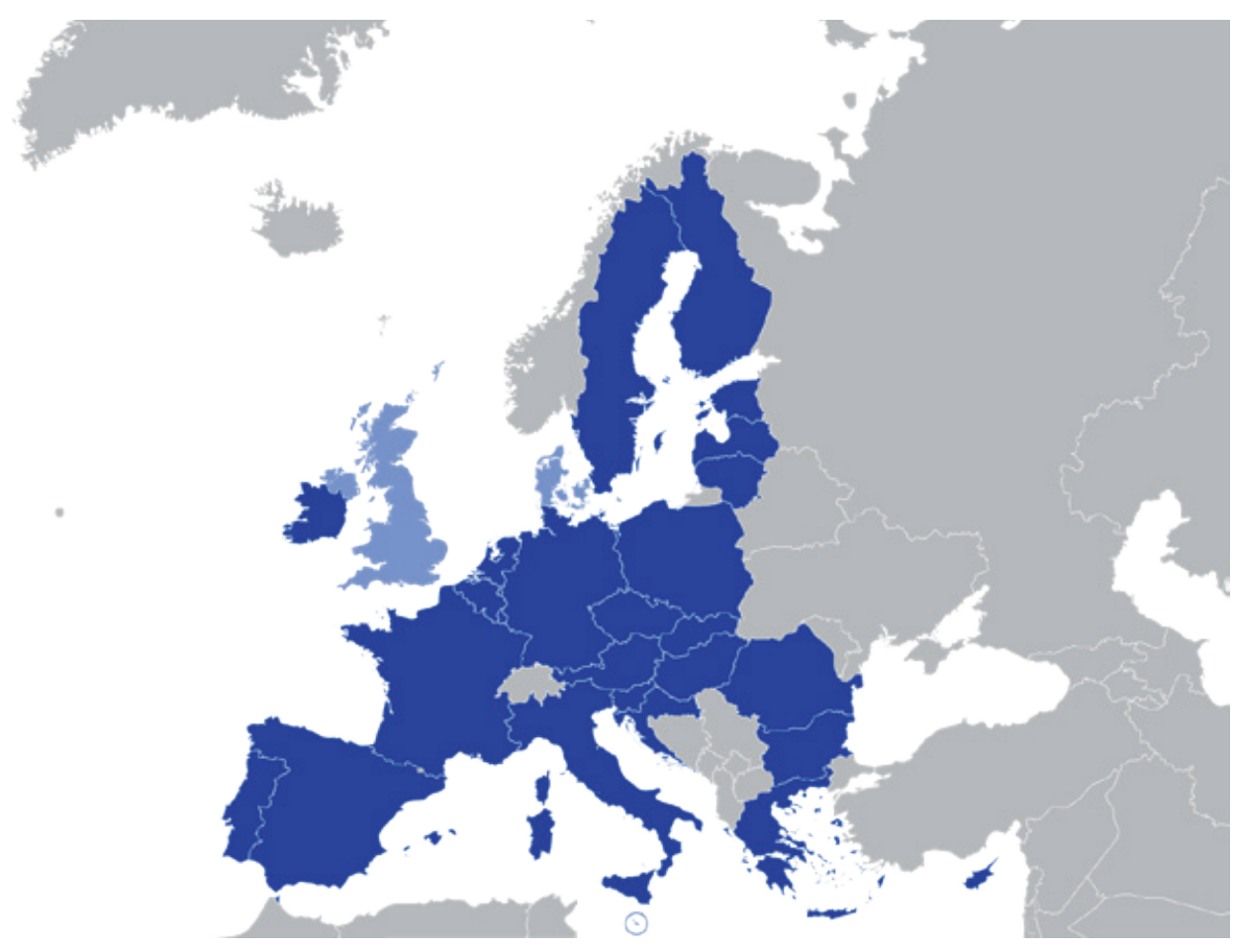

ILL: NordNordWest, https://creativecommons.org/licenses/by-sa/3.0/de/legalcode

Kort over medlemmerne af PESCO (Permanent Structured Cooperation); mørkeblå: PESCO-medlemmer, lyseblå: andre EU-medlemmer 
pa-Kommissionen desuden gentaget, at initiativer som PESCO og Den Europæiske Forsvarsfond skal styrke EU's operationelle og industrielle autonomi.

For de deltagende medlemsstater er PESCO det vigtigste instrument til fremme af fælles sikkerhed og forsvar $i$ et område, hvor der er brug for mere sammenhæng, kontinuitet, koordinering og samarbejde. Baseret på en modulær tilgang vil 34 forsvarsprojekter blive udviklet i forskellige grupper af medlemsstater, der dækker områder fra operationel beredskab til udvikling af kapaciteter.

Den effektive udvikling af de forskellige moduler samt deres komplementaritet og ambition om at styrke Europas strategiske autonomi over tid vil være lakmusprøven for PESCO i de kommende år. For at øge produktionen af det europæiske forsvar og maksimere effektiviteten af forsvarsudgifterne i Europa vil det være nødvendigt med mere tilpasning og en mere fælles strategisk tilgang på tværs af medlemsstater og EU-institutioner.

Strategisk autonomi bør ses som friheden til at tage ansvar for egen sikkerhed samt for den globale dagsorden om at bevare den liberale verdensorden, der er under stigende pres. EU befinder sig i øjeblikket i centrum for et net af politiske, økonomiske og sikkerhedsmæssige afhængigheder. Nogle er velkomne, men andre mindre. Hvis Europa skal undgå at ende som en andenrangsaktør i det 21. århundrede - og i øvrigt undgå relativ geopolitisk forfald - så er medlemslandene nødt til at tænke grundigt over det strategiske miljø, de sandsynligvis vil arve i de kommende årtier med den nuværende kurs, og sammenholde det med det strategiske miljø, de ønsker. Hvis EU's vigtigste strategiske mål er at opretholde den meget multilaterale orden, der har givet Unionen mulighed for at blomstre, så skal der lægges større vægt på afhængigheder, som EU har med Rusland, Kina og andre lande, som underminerer Europas handleevne, sikkerhed eller velfærd.

Der er derfor behov for en mere moden tilgang til spørgsmålet om transatlantisk og generel europæisk byrdefordeling, hvor EU kan tage et mere passende niveau af strategisk autonomi i sikkerhed og forsvar uden at blive anklaget for at udfordre den transatlantiske forbindelse eller underminere NATO.

\section{Bedre og mere fælles forsvar}

Europa kan ønske sig nok så meget at tage mere ansvar for egen sikkerhed og fremtid, men uden en mere udbygget og velsmurt forsvarsmaskine kommer man ikke langt.

I øjeblikket er 80 pct. af de europæiske forsvarsopkøb og mere end 90 pct. af forsvarsrelaterede forsknings- og teknologiprogrammer stadig i gang på nationalt plan. Det betyder at der bruges mere end seks gange så mange forsvarssystemer $\mathrm{i}$ Europa som i USA. I alt 36 forsvarsplatforme og systemer er i øjeblikket i produktion i Europa mod kun 11 i USA. Et sådan overlap fører til manglende storskalafordele og efterlader færre midler til udvikling af andre kapaciteter, som i sidste ende betyder færre militære kapaciteter for medlemsstaterne.

Samtidig ses hurtige fremskridt inden for kunstig intelligens (AI), kvantecomputere, bioteknologi, rum- 
I mødet med fælles sikkerhedspolitiske udfordringer fra syd såvel som øst har både medlemsstater og allierede gentagne gange understreget, at et stærkere EU og et stærkere NATO er til gensidig nytte og sikkerhed. missionen lancerede et pilotprojekt i april 2017 med et budget på 90 mio. euro frem til 2019 og modtog 24 indlæg fra konsortier via det Europæiske Forsvarsa- teknologi samt autonome og elektromagnetiske våben. Det er tilsammen teknologier med potentiale til at skabe usikkerhed om EU's fremtidige sikkerhedsmiljø. Det er usandsynligt at Europa vil have råd til at investere $i$ alle disse forskellige teknologier, hvis medlemsstaterne gør det alene. Men gør vi det sammen, så er potentialet stort.

I tæt samarbejde har medlemsstaterne og Europa-Kommissionen derfor sat gang i den europæiske forsvarsmotor. I juni 2017 foreslog man en europæisk forsvarsfond til finansiering af samarbejdsorienterede forskningsprojekter samt at udnytte de nationale investeringer med EU-penge til at overkomme den mest risikable fase af udviklingen af militærteknologi og produkter fra pilotprojekter til prototyper.

Tilgangen giver Europa et håndfast instrument til at stimulere mere forsvarssamarbejde på tværs af kontinentet - og en refleks til at tænke i de baner samtidig med at man opfordrer til bedre udgifter og håndterer mangelfuldhed og prioriterede behov. Fonden skal nu udvikles til et fuldt udbygget, dedikeret flerårigt og forudsigeligt europæisk forsvarsprogram, der mobiliserer en pct. af det næste EU-budget.

Forløbet er designet til at producere konkrete resultater i perioden 20192020 , allerede inden EU's næste budget for 2021-2027 der skal forhandles på plads i det kommende år. Europa-Kom- gentur (EDA). I begyndelsen af sidste år modtog fem projekter støtte, herunder OCEAN 2020 der er et fælles teknologisk forskningsprojekt i maritim overvågning med 42 partnere fra 15 europæiske lande, som hermed blev det første eksempel på et tvær-europæisk militært forskningsprogram i EU-regi.

Næste skridt er det europæiske forsvarsindustrielle udviklingsprogram, der skal igangsættes i 2019 og vil have et budget på 500 mio. euro til samarbejdsprojekter løbende over to år. Programmets succes vil afhænge af dets evne til at definere og tiltrække den rigtige slags projekter af høj kvalitet: der skal være overensstemmelse med EU's prioriteter; de skal lukke et hul i europæiske kapaciteter; og de skal helst have deltagelse fra et bredt spektrum af industriaktører - bl.a. små og mellemstore virksomheder til større og mere slagkraftige koncerner på tværs af EU's medlemsstater.

\section{Stærkere EU - stærkere NATO} Udviklingen i EU foregår i stærkt samarbejde med NATO. I mødet med fælles sikkerhedspolitiske udfordringer fra syd såvel som øst har både medlemsstater og allierede gentagne gange understreget, at et stærkere EU og et stærkere NATO er til gensidig nytte og sikkerhed.

Siden den fælles EU-NATO deklaration blev underskrevet ved NATO-topmødet i Warszawa i 2016, har samar- 
bejdet mellem de to institutioner nået et hidtil uset niveau, og indtil videre er 74 både konkrete og brede tiltag under implementering i nøgleområder for at styrke Europas samlede sikkerhed.

Det blev endnu engang slået fast med den nyligt vedtagne EU-NATO-deklaration fra juli 2018, hvor generalsekretær Jens Stoltenberg, formand Jean-Claude Juncker og formand Donald Tusk fremlagde en fælles vision: En europæisk forsvarspolitisk dimension vil ikke reducere, men tværtimod styrke Europas bidrag til den transatlantiske byrdedeling og $\varnothing$ ge den europæiske evne til at agere sammen med NATO eller selvstændigt i områder af fælles sikkerhedsmæssig interesse, både strategisk og operationelt.

Tre vigtige resultater af den nuværende strategiske komplementaritet mellem EU og NATO kan fremhæves på dette tidspunkt.

Først og fremmest gælder det militær mobilitet. EU har fremsat en handlingsplan for militær mobilitet, støttet af et budgetforslag på 6,5 mia. euro. Formålet er at validere kravene i midten af 2018 og påbegynde gennemførelsen i 2019 for at forenkle de militære styrkers mobilitet, når det er nødvendigt, samt stimulere $ø$ konomisk vækst i fredstid. Desuden vil 24 EU-medlemsstater udvikle nationale mobilitetsplaner og forkorte grænseovergangstider under et PESCO-projekt ledet af Nederlandene. Disse bestræbelser vil være nyttige i NATO's nye Readiness Initiative 'Four Thirties'.

Det andet store fremskridt er den fælles bekæmpelse af hybridtrusler. I 2017 gennemførte EU- og NATO-staber for første gang en fælles hybridøvelse for at opnå en fælles forståelse af egen modstandsdygtighed og videreudvikling af synergien $\mathrm{i}$ krisehåndtering. Der er allerede planlagt nye øvelser i 2018, 2019 og 2020.

Komplementariteten mellem EU og NATO er også styrket med bl.a. EU's energisikkerhedsstrategi og energifællesskab samt ved EU's generelle indsats og seneste handlingsplan mod online propaganda og disinformation. På cybersikkerheden styrker NATO integriteten af militær infrastruktur, mens EU's nylige cybersikkerhedspakke øger europæisk cybersikkerhed og skaber nye mekanismer til krisehåndtering som $\mathrm{fx}$ det nye cybersecurity-blueprint. Ligeledes ses et nyt PESCO-projekt ledet af Litauen, der sigter mod at forbinde nationale agenturer som Cyber Rapid Response Teams til styrkelse af civil-militær modstandsdygtighed og gensidig bistand som reaktion på større cyberhændelser.

For det tredje ses en stigende fælles projicering af stabilitet gennem bekæmpelse af terrorisme og kapacitetsopbygning i tredjelande. Den fælles opfølgning på ISIS’ nederlag i Irak fra EU og NATO med udsendelse af rådgivere viser bl.a. fordelene ved at agere sammen uden overlap. Mens NATO giver militær rådgivning til det irakiske forsvarsministerium, har EU's rådgivende CSDP-mission i Irak, med bidrag fra 13 medlemsstater, støttet indenrigsministeriet og den nationale sikkerhedsrådgiver for menneskerettigheder, reform af sikkerhedssektoren og bekæmpelse af terrorisme. EU-engagementet omfatter også politisk, humanitær og udviklingsindsats, der bygger på 650 mio. euro til Irak i perioden 2014-2017. 
Med de nye tiltag vil diskussionen om de strategiske rammer for Europas fremtidige sikkerhedsarkitektur kun flytte længere ind i EU-apparatet - og længere væk fra dansk indflydelse.

Deling af trusselsvurderinger, koordinering af svar og skabelse af pragmatiske løsninger samt strategiske rammer vil yderligere styrke komplementariteten mellem EU og NATO. For fremtiden kunne samarbejde om bekæmpelse af terrorisme og kapacitetsopbygning øge fordele for øget grænsesikkerhed. Samarbejde om kunstig intelligens, supercomputing, big data og cryptocurrency kunne samtidig skabe fælles projekter med at omdanne fælles data til fælles sikkerhed.

For de europæiske borgere producerer det voksende samarbejde mellem EU og NATO allerede konkrete fordele på tværs af bordet - fra 'tweets to tanks', dvs. fra at opbygge modstandsdygtighed mod disinformationsangreb til muligheden for at indsætte væbnede styrker, når det er nødvendigt på Europas sydlige eller østlige flanke.

\section{Strategisk diskussion i EU}

Danmark befinder sig i stigende grad i et paradoks. Historisk set er forsvarsforbeholdet rodfæstet i ønsket om, at forsvarspolitikken skal behandles i et mellemstatsligt forum snarere end drives af et centralt europæisk organ.

Den nuværende struktur i det europæiske forsvarssamarbejde tilgodeser denne tilgang. Medlemslandene kan sammen lede udviklingen af ny forsvarsteknologi i Forsvarsfonden og et dybere fælles samarbejde i PESCO med støtte fra de europæiske institutioner.

Men Danmark er ikke med. Og med de nye tiltag vil diskussionen om de strategiske rammer for Europas fremtidige sikkerhedsarkitektur kun flytte længere ind i EU-apparatet - og længere væk fra dansk indflydelse.

Danmark har traditionelt kunnet tale med på de forbeholdslagte områder via det voksende EU-NATO-samarbejde, men efterhånden som vægtskålen for debatten læner sig mod hybridtrusler på europæisk grund og mere teknisk kapacitetsopbygning, med udgangspunkt $\mathrm{i}$ PESCO og andre forsvarsrelaterede fora, så bliver billedet mere mudret for den danske position.

De nye PESCO-projekter dækker nemlig ikke kun over operationelle initiativer som cyberforsvar og støtte af FN-missioner, men også strategiske-økonomiske tiltag til fremme af militær mobilitet samt udvikling af fremtidens forsvarsteknologi. Og ikke mindst spørgsmålet om strategisk autonomi og hvordan EU kan bidrage til NATO som en troværdig europæisk partner.

Der vil således være en høj grad af komplementaritet mellem EU og NATO i fremtidens europæiske sikkerhedsarkitektur, men Danmark kommer i stigende grad til at stå uden for døren, når beslutningerne træffes om den strategiske retning for Europa.

For at kunne følge med i udviklingen med det nuværende forsvarsforbehold, og samtidig fă indflydelse, er der pludselig kun én logisk mulighed tilbage: at arbejde for at indlemme forsvarspolitikken i Kommissionen, hvor medlems- 
landene per automatik konsulteres om nye politiske og økonomiske initiativer. Men det har der traditionelt set ikke været interesse for.

Vægten af de nye programmer i den Europæiske Forsvarsfond kommer til at ligge på områder af særlig dansk interesse og med stort potentiale for danske virksomheder - højteknologi, radar, droner, robotter og med tiden kunstig intelligens (AI).

Men selvom danske virksomheder har adgang til midlerne og samarbejdet i fonden, så vil Danmark ikke kunne være med til at sætte retningen for initiativerne i PESCO, som fonden er tænkt bundet op på. Det er synd, fordi dansk sikkerhedspolitisk kompetence og lederskab er en efterspurgt ressource, som de seneste årtier har vist. Observatørstatus i det europæiske forsvarsagentur (EDA) ville være et godt skridt frem, men kan ikke give indflydelse. Samtidig må tiden vise, om andre medlemsstater accepterer idéen, om at man kan blive 'observatør', når man også kunne blive medlem.

\section{Danmark med i samtalen?}

PESCO og Forsvarsfonden er nu blevet til virkelighed, og er ikke længere blot abstrakte idéer. Hoveddelen af arbejdet ligger stadig foran - når penge og politik skal laves til nye kapaciteter, et fælles forsvarsmarked og et dybere samarbejde - men virkeligheden er ved at løbe fra det danske forbehold.

Samtidig løber samtalen om en fælles strategisk kultur og en fremtidig europæisk forsvarsunion videre mellem Paris, Berlin og Bruxelles. Her er idéen stadig mere abstrakt, men visionen om et stærkere Europa, der kan stå på egne ben - i fuld komplementaritet med NATO og den transatlantiske artikel 5 - er klar.

Hvis Danmark vil være med til at forme den nye europæiske virkelighed og sikkerhedsarkitektur, og de idéer, der løber forud for dem, så nytter det ikke noget alene at være observatør. Den nye udenrigs- og sikkerhedspolitiske strategi berører dette paradoks, men tiden - og det kommende Folketingsvalg - må vise, hvordan man har tænkt sig at håndtere det uden en afstemning om det danske forsvarsforbehold. 